\title{
Road accidents in the early days of the automotive industry
}

\begin{abstract}
The first recorded road fatality happened over 140 years ago. Since then, road accidents have become one of the main causes of concern in almost every country in the world. Nowadays, fatal motor vehicle crashes occur at an interval of 50 seconds and injuries happen every two seconds. According to the WHO, the world road death toll is nearly 1.3 million and 20-50 million of people have been badly injured in road accidents and usually require long and expensive treatment. This paper looks at the issue of road accidents in the earliest days of the automotive industry. The article looks at the first laws, which were introduced to improve road safety. Virtually every member of society is somewhat affected by road transport. All traffic participants are at risk of an accident to a certain degree which is why reducing this risk should become a priority.
\end{abstract}

Keywords: car accidents, automotive, road safety.

DOI: $10.1515 /$ pjph-2015-0049

\section{INTRODUCTION}

The first vehicles that appeared at the end of the $19^{\text {th }}$ century were considered a curiosity and they initially received shrugs, half-smiles or even they were met with contempt. The real struggle between the car and traditional horse carts happened during the interwar period. A few years later, right after World War II, the car has gained the supreme position. Since then, nobody has tried to contest the domination of motor vehicles. Because of this, there were numerous attempts to improve them, like efforts to make the manufacturing process faster, in order to make it more compatible with the conditions in some countries, still trying to heal the war wounds and rebuild the industrial base [1]. Currently, traveling by car has become a part of daily life, one of individual and collective development goals, as well as an important social process. Even though the development of the automotive industry was inevitable, it has unfortunately been associated with a series of negative phenomena, with vehicle crashes being the most tragic.

\section{Road accidents}

Vehicle crashes have always been a part of the car experience. In 1771, Nicolas Joseph Cugnot caused the first road accident by crashing a self-built, improved version of the world's first steam-powered vehicle into a wall. The vehicle was badly damaged as a result of the accident [1]. The first road casualty was an Anglican pastor from the town of Redruth. He died of fright at the sight of a loud and fast-moving model of "a steam engine on wheels", which was designed by William Murdock. This event took place in 1786 [1,2]. The world's first fatality caused by a road accident was reported to happen on August 31, 1869 in County Offaly in the UK. While traveling as a passenger of an experimental steam-powered vehicle built by her cousins, an Irish Mary Ward fell out of the vehicle on a bend and under its steel wheels and was run over. She died as a result of injuries [3].

In the middle of the $19^{\text {th }}$ century, the number of steam vehicles appearing on the streets of Europe and the US was constantly on the rise. Nonetheless, these vehicles were still intriguing for other road users and continued to cause accidents because of the careless behavior of pedestrians or the fact that they were scaring the cart-drawing horses. This increase in the number of vehicles and their speed meant the development of road network necessary, as well as introducing some regulations as to the way they were used. In order to improve public safety, the English Parliament passed the Locomotives on Highways Act in 1865. The Act required all motor vehicles to travel at a maximum speed of $4 \mathrm{mph}$ outside cities or towns and to $2 \mathrm{mph}$ in cities. The law also required a certain number of the crew to be present when a steam vehicle was moving. According to the Act, a man carrying a red flag should be walking some 60 yards ahead of the motor vehicle, so as to warn others about the coming danger $[1,4]$. The Act appeared to be one of the main reasons for the delay in the construction of internal combustion engine vehicles for the English. In 1896, the Act was repealed and the speed limit increased to $14 \mathrm{mph}[1]$.

\footnotetext{
${ }^{1}$ Medical University of Warsaw, Department of Disaster Medicine, Poland

${ }^{2}$ Medical University of Lublin, Department of Expert Medical Assistance with Emergency Medicine Unit, Poland

${ }^{3}$ Medical University of Warsaw, Department of General and Transplantation Surgery, Poland

${ }^{4}$ National Medicines Institute, Warsaw, Poland
} 
The first road accident involving a vehicle fitted with an internal combustion engine took place in 1891 in Ohio City, USA. The vehicle driven by James William Lambert hit the root of a tree, the driver lost control of the vehicle and it turned over and received extensive damage, yet the driver and the passenger suffered minor injuries [5]. The world's first collision of two motor vehicles occurred in 1893 in Europe and caused minor injuries to the drivers [6]. The first fatal casualty of a road accident involving a vehicle powered by an internal combustion engine was Bridget Driscoll. She died on August 17, 1896 in London as she tried to run across the street in front of an approaching vehicle [6,7]. It happened only a few weeks after the new act increasing the speed limit for motor vehicles in the UK was introduced. The investigation of the accident resulted in recognizing the death of Bridget Driscoll as accidental and the coroner, William Percy Morrison, commented as follows: “(...) I hope such a thing will never happen again" [8]. Another pedestrian, Henry H. Bliss, was reported to be the first motor vehicle fatality in the US. He died on September 13, 1899 after he was hit by a car at West 74 Street and Central Park West in New York [9]. The first known victim of a road accident requiring hospitalization because of a broken leg was a cyclist name Ebeling Thomas. He was hit on Western Boulevard in New York on May 30, 1896. The perpetrator, Henry Wells, in turn, was the first person to be arrested for causing a road accident [5]. The first passenger to have died in a road accident was Major James Stanley Richer. The accident occurred on February 25, 1899 on Grove Hill Street in Harrow on the Hill. The wheel of his Daimler Wagonette has fallen off and hit a wall. The driver and the passenger were thrown off the vehicle. Edwin Sewell died immediately, whereas the passenger never regained consciousness and died four days after the accident $[2,4]$.

Nevertheless, the highest accident count involving motor vehicles was associated with car races which were hugely popular at the turn of the $19^{\text {th }}$ century. The rise of the accident rate was caused by a rapid speed increase at the time, low safety levels they offered and the fact that neither the spectators nor casual passers-by were keeping a safe distance from the cars. In addition, there was no infrastructure that would be suitable for faster cars and the drivers were reckless, which was also propelled by the lack of road regulations $[6,10]$. The first auto racing competition was organized in France in 1894 by the French Automobile Club. All of these races, as well as the Gordon Bennet Cup, were taking place on public roads. In 1897, a driver taking part in the competition died. He was the second fatal casualty of car racing in Europe. The same year, another racing driver was a victim of a car accident. In 1903, during the Paris-Madrid leg of the race, four drivers, four spectators, two soldiers and a girl who was trying to cross the street all died and many more were injured on the road to Bordeaux. The competition was stopped and car races were banned from public roads. Also, the work on traffic regulations was sped up $[1,6]$. The first car racing event on a closed and separate circuit took place in 1903 in the UK. It was a step further from the dangerous tradition of racing without speed limits on public roads [1].
Apart from road races, some other forms of racing, like speed trials, were organized. During this particular competition, drivers were supposed to determine the maximum speed which a motor vehicle can reach in the most conducive road and weather conditions [1]. The first such trial was carried out in 1898 during a competition organized by the French automotive magazine La France Automobile. Count Gaston de Chasseloup-Laubat (1867-1903) was the race car driver who broke the first speed record on December 18, 1898 in Achères, driving a Jeantaud electric car. The rule for setting the record was simple: the judges measured the amount of time needed for the car to cover 0.62 of a mile. The French driver did that in 57 seconds. It was later found out that the record was in fact $39 \mathrm{mph}$ [11]. Subsequent speed records were also established by electric cars. In 1899, a Belgian electrical engineer and race car driver Camille Jenatzy became the first person to break the speed record of $62 \mathrm{mph}$ and in fact registered the speed of $65 \mathrm{mph}$ while driving a special aerodynamic electric car - La Jamais Contente $[12,13]$. At the turn of the $19^{\text {th }}$ century renowned car manufacturers attempted to break the speed record and the names of the drivers who managed to reach those, at that time, mindblowing speeds also became well-known all around the world [1]. Automobiles powered by steam, internal combustion and electric engines were driven on separate sections of public roads, wide beaches, recently-built race tracks and other suitable places in the attempt to set a new world record. On January 12, 1904 Henry Ford managed to do just that in a car powered by an internal combustion engine on a frozen Lake St. Clair. The 1.8-liter and four-cylinder engine of the racing car dubbed Ford 999 was designed by Henry Ford and reached the speed of $91.37 \mathrm{mph}$. It wasn't until two years later, in January 1906 in Daytona Beach that the barrier of $124 \mathrm{mph}$ was broken by an American, Fred Marriott, who drove a steam-powered Stanley Steamer. The new speed record on land was $127 \mathrm{mph}$. In fact, Stanley Steamer was also the last car other than powered by an internal combustion engine to beat the world speed record on land $[14,15]$. Three years later, the barrier of $124 \mathrm{mph}$ was be broken by a car with an internal combustion engine. It was reported on November $6^{\text {th }}, 1909$ in the UK on the Brooklands race track and the Benz 200 HP, later called Blitzen Benz, was driven by Victor Hémery. He managed to maintain an average speed of $126 \mathrm{mph}$ on the distance of 1 kilometer and $116 \mathrm{mph}$ on the distance of 1 mile [15]. It was a new world record established by a car with an internal combustion engine and for the first time electronics was employed for the time-keeping. Benz $200 \mathrm{HP}$ was the biggest sensation of its day, akin to ultrafast supercars manufactured these days all over the world. The speed of $124 \mathrm{mph}$ was an outstanding result, judging by the standards of 1909, something similar to today's $248 \mathrm{mph}$.

Aside from beating new speed records, numerous competitions were held during the early stages of car development, like driving the longest distance without a stop or climbing up a hill. Such events took place mainly in the US, as the condition of road infrastructure was quite poor there at that time [1]. 
The popularity of car racing events required the engineers to constantly improve the design and the manufacturers to boost quality. The period between 1900 and 1905 significantly influenced the automotive industry for the years to come. Then, cars have become self-propelled vehicles, sporting a distinct, unique look that was not based on carts pulled by horses. These changes were introduced in the wake of the accident of 1900 that took place at a car racing event near Monte Carlo. The driver of a Daimler-produced car died and the analysis of the accident led to the assertion that in order to increase safety, the wheelbase had to be higher than the wheel track, and that the length of a car should exceed its width [1].

Car races in the early days of the automotive industry showed that the innovation outpaced the technical condition of roads as well as the development of traffic regulations. They also proved that car racing, too, was the driving force behind the development of the automotive industry and road safety [1].

In 1892, France passed the first directive which limited the maximum speed of motor vehicles and introduced mandatory use of silencers and adequate brakes. Next, the first traffic code was devised which regulated such issues as the right of way at intersections or identification of road accidents' perpetrators [10]. World's first license plates were issued by the French police in 1893 and the requirement of having them applied only to the citizens of Paris; the German police introduced license plates in 1896. However, the prototype of contemporary license plate systems came into being in the Netherlands and it was called "road license". The license plate consisted of a series of digits with no indication of the owner's place of living. Countrywide license plates began to be issued in the Netherlands in 1898 [14]. In 1922, Poland introduced such a system through the regulation of the Minister of Public Works. It determined that the license plate number would comprise one or two letters denoting the province where the car was registered and a series of digits representing the registration number; the letters were red and the digits black. The front plate indicated the city code and the rear one the province [6].

In 1900, William Phelps Eno published an article on the need to reform the traffic code in towns and cities. This American businessman - known as "father of traffic safety" - was the innovator behind traffic safety. Although he never learned to drive himself, he designed traffic plans for New York, London and Paris. In 1903 he created a city traffic code for New York. He also designed the stop sign, oneway street, taxi stand, safety island for pedestrians and the roundabout (including the one around the Triumphal Arch in Paris). The rules created by William Phelps Eno are used until today [16]. The Motor Car Act was introduced in the UK on January 1, 1904. In light of this regulation, all vehicles were expected to have a license plate on, which meant that they had to be registered. In addition, drivers were expected to obtain a special license which required completing a special form and paying a fee at the post office. Back at that time, drivers were not expected to pass a driving exam [2,17]. In 1905 the English police made, for the first time, use of a device for measuring the speed of cars (the speed limit was at that time $20 \mathrm{mph}[6,10]$.
Although various regulations aiming at improving the road safety were introduced, the number of casualties increased dramatically. In 1906, vehicle crash-related deaths became a separate category in the U.S. Police data [18].

\section{CONCLUSIONS}

No single invention has attracted greater attention of so many scientists, technicians, merchants, dreamers, adventurers and profiteers than the car. Its presence spurred building of better roads, creating new branches of industry as well as car or car parts and equipment manufacturing plants. Design studios were coming up with new technological solutions for cars and new forms of motor sport competitions came into being. The car redefined military strategies, crafts, utility delivery systems and even human relations.

The first fatal road accident happened over 140 years ago and road accidents have been one of the main issues of health and social policies of countries in every continent of the world. Nowadays a fatal road accident occurs in some part of the globe every 50 seconds on average and it results in injuries every two seconds. According to WHO, the world's road death toll is nearly 1.3 million and 20-50 million of people get badly injured in road accidents and mostly require long and costly treatment $[19,20]$.

Road transport exerts influence over virtually every member of the society and the most active participants of it - the drivers - comprise not only those at economically productive age, but also the elderly and the youth. As traffic participants, we all run the risk of an accident to a certain degree and that is why it should be of everybody's interest to reduce this risk.

\section{REFERENCES}

1. Wu Xu, Hu S, Cui Y, Ma Y. Study on Evaluation of Harmonious Development Between Transportation and Economy. JBJU (Social Sciences Edition). 2005;2:004.

2. Wolfgang K, Rybicki J, Mauve M. On the nature of inter-vehicle communication. Communication in Distributed Systems 2007 ITG-GI Conference. VDE; 2007.

3. Anderson D, Anderson J. Electric and hybrid cars: A history. McFarland, Jefferson; 2004.

4. Cummings P, Rivara FP, Olson CM, Smith KM. Changes in traffic crash mortality rates attributed to use of alcohol, or lack of a seat belt, air bag, motorcycle helmet, or bicycle helmet. United States, 1982-2001. Injury Prevention. 2006;12:148-54.

5. Gartman D. Three Ages of the Automobile The Cultural Logics of The Car. Theory, Culture \& Society. 2004;21:169-95.

6. Williams K, Haslam C, Johal S, Williams J. Cars: Analysis, History, Cases. New York: Berghahn Books; 1994

7. Struben J, Sterman J. Transition challenges for alternative fuel vehicle and transportation systems. Environ Plan B: Plan Des. 2008;35:1070-97.

8. Truffer B. Society, technology, and region: contributions from the social study of technology to economic geography. Environ Plan B: Plan Des. 2008;40:966.

9. Szczepaniak C. Cywilizacja a motoryzacja. Czas Tech. Mechanika. 1998;95:3-14.

10. Bijker WE, Hughes TP, Pinch T. The social construction of technological systems: New directions in the sociology and history of technology. Cambridge: MIT Press; 2012.

11. Bengry-Howell A, Griffin C. Self-made motormen: The material construction of working-class masculine identities through car modification. J Youth Stud. 2007;10:439-58.

12. Ranney TA. Models of driving behavior: a review of their evolution. Accid Anal Prev. 1994;6:733-50. 
13. Tomson T, Beghi E, Sundqvist A, Johannessen SI. Medical risks in epilepsy: a review with focus on physical injuries, mortality, traffic accidents and their prevention. Epilepsy Res. 2004;1:1-16.

14. Scott I. Drive On! A Social History of the Motor Car. Injury prev. 2004;4:249-57.

15. Híjar M, Carrillo C, Flores M, Anaya R, Lopez V. Risk factors in highway traffic accidents: a case control study. Accid Anal Prev. 2000;5:703-9.

16. Chan CC. The state of the art of electric, hybrid, and fuel cell vehicles. Proceedings of the IEEE. 2007;4:704-18.

17. Klauer SG, Dingus TA, Neale V L, et al. The impact of driver inattention on near-crash/crash risk: An analysis using the 100-car naturalistic driving study data. Washington: National Highway Traffic Safety Administration; 2006.

18. Lee JD, Young KL. Driver distraction: Theory, effects, and mitigation. CRC Press, Boca Raton; 2008.

19. Goniewicz K, Goniewicz M. Europejskie inicjatywy na rzecz poprawy bezpieczeństwa ruchu drogowego. Bezp Pracy. 2014;9:24-9.

20. Goniewicz K, Goniewicz M, Pawłowski W, Fiedor P. Road accident rates: strategies and programmes for improving road traffic safety. Eur J Trauma Emerg Surg. 2015, DOI: 10.1007/s00068-015-0544-6.

\section{Corresponding author}

Krzysztof Goniewicz

81 A Zwirki i Wigury Str, 02-091 Warszawa

tel.: +48 (0-22) 5720545,5720536

E-mail: krzysztof.goniewicz@wum.edu.pl 